Rhode Island College

Digital Commons @ RIC

What's Water Got to Do with It? Place-Related Symbolic Meanings Alter Residents' Perceived Effects of Coastal Infrastructure

Bryce B. DuBois

Katherine Lacasse

Aaron J. Ley

Follow this and additional works at: https://digitalcommons.ric.edu/facultypublications

Part of the Other Life Sciences Commons, and the Other Psychology Commons 


\title{
What's Water Got to Do with It? Place-Related Symbolic Meanings Alter Residents' Perceived Effects of Coastal Infrastructure
}

\author{
Bryce B. DuBois \\ Rhode Island School of Design \\ Katherine Lacasse \\ Rhode Island College \\ Aaron J. Ley \\ University of Rhode Island
}

Authors and affiliations: Bryce B. DuBois, PhD., History, Philosophy and Social Sciences Concentration, Rhode Island School of Design, Providence, Rhode Island, USA, bdubois@ risd.edu; Katherine Lacasse, PhD. Department of Psychology, Rhode Island College, Providence, Rhode Island, USA, klacasse@ ric.edu; Aaron J. Ley, Ph.D., Department of Political Science, University of Rhode Island, Kingston, Rhode Island, USA, ajley@uri.edu.

Citation for Article: DuBois, B. B., Lacasse, K., \& Ley, A. J. (2021). What's water got to do with it? Place-related symbolic meanings alter residents' perceived effects of coastal infrastructure. Ecopsychology, 13(2), 123-132. https://doi.org/10.1089/eco.2020.0051 


\begin{abstract}
The symbolic meanings residents associate with their local bodies of water and coastal infrastructure can shape their perceptions of the infrastructure's effects. In this case, we conduct a survey $(N=168)$ to examine residents' perceptions of visibly disruptive, yet environmentally protective cooling towers attached to a long-standing coal-fired power plant on Mount Hope Bay. Residents' symbolic meanings of the bay corresponded predominantly with aesthetic, ecological, or recreational themes, whereas their symbolic meanings of the towers also focused on aesthetics as well as the towers' function or uselessness. Although residents generally perceived the towers as having negative effects on different aspects of the bay community overall, those who reported ecological meanings of the bay or functional meanings of the towers perceived that the towers offered significantly more positive ecological and health impacts. They were also more likely to differentiate positive ecological and health effects from the towers' more negative aesthetic and financial impacts. This offers evidence for the important role of symbolic meanings in shaping perceptions of coastal infrastructure and demonstrates how specific understandings of the bay and the infrastructure itself can lead to more nuanced perceptions of the positive and negative effects of such projects.
\end{abstract}

Keywords: place attachment, place-related symbolic meanings, public opinion, energy infrastructure 


\section{Introduction}

Now, more than ever, coastal communities find themselves in rapidly changing environments due to climate change, coastal development, and environmental degradation. Societal responses to these changes include infrastructural or landscape adaptations that may conflict with longstanding environmental features, challenging the meanings of coastal areas among residents who often feel great attachment to the place (Devine-Wright \& Howes, 2010; Adger et al., 2009). Place attachment, or the sense of bond between a person and a place, is particularly useful in explaining residents' individual or collective actions to protect a place from disruptions that interfere with their emotional and identity-related connections to the place (Devine-Wright, 2009; Manzo \& Perkins, 2006). However, while place attachment captures the strength of a relationship with a place, place related symbolic meanings (PRSMs) capture the unique descriptive elements of a place that differ from person to person. In this study, we aim to examine how the variations in place attachment and PRSMs alter how residents perceive a visibly disruptive, yet environmentally-protective infrastructure along the shore of their local bay.

\section{Literature Review}

The concept of sense of place, typically measured through place attachment and place meaning, is used in the social sciences to study contextually relevant aspects of people-place relationships. People develop meanings about places based in emotional entanglements and can also develop identities related to meaningful places (Proshansky et al., 1983), based on 'lived experience' in a place over time (Manzo \& Perkins, 2006). Individuals may also develop place attachment through the building up of emotional sentiment about a place (Low \& Altman, 1992). PRSMs represent the various ways that people subjectively experience local places separate from 
place attachment (Stedman, 2016).

For example, many highly attached people may hold distinct PRSMs, differentially valuing the place's aesthetic beauty, recreational opportunities, ecological diversity, or their familial ties to the place. PRSMs can include cognitive, emotional, and behavioral responses (Wynveen et al., 2012), and such meanings differ among groups and can alter people's particular goals of stewardship (Enqvist et al, 2019). Studies of visitors to marine environments find that PRSMs relate to the opportunities afforded by the physical environment, including recreational activities, social and communal activities, and affective elements of place (Tonge et al., 2013).

Furthermore, the role of general waterbody meanings may influence perceptions of risk from hazards such as flooding. For example, some individuals maintain rather simple, positive PRSMs with waterbodies and therefore tend to perceive lower flooding risks, while others carry distinct and potentially conflictual PRSMs of the water itself (i.e., positive associations with water) and waterbodies (i.e., flooding risk) that lead to more complex risk perceptions (Quinn et al., 2019).

Over a decade of work on infrastructure siting projects demonstrates that local context needs to be considered in addition to the environmental benefits of these projects. Public opposition to such projects was often viewed as NIMBY-ism (Not in My Back Yard), conceptualizing residents as ignorant, irrational, or selfish (Freudenberg \& Pastor 1992). More contemporary work has found that external factors, such as where the project is sited and how well there is 'place-technology fit,' are key to determining whether infrastructure causes a disruption (i.e., Devine-Wright, 2009; Devine-Wright \& Wiersma, 2019; McLachlan, 2009). For example, although the environmentally beneficial aspects of wind-turbines do not improve their perceived aesthetic quality for all residents, peoples' visual attitudes about local wind turbines vary (Rand \& Hoen, 2017), and residents with positive visual attitudes of wind turbines are more 
supportive of such projects because of their perceived environmental benefits (Firestone et al., 2015; Saito, 2004). Of particular importance is residents' socially constructed PSRMs, which have been shown to moderate the connection between place attachment and the acceptance of an infrastructure project (Devine-Wright 2011; Devine-Wright \& Howes, 2010; Stedman, 2002).

When residents learn about an infrastructure project, their specific PRSMs can often predict their response (Clarke et al., 2018; Devine-Wright, 2011; Devine-Wright \& Howes 2010), although not in all cases (Stedman, 2002). For example, PRSMs related to the visual, scenic beauty, and restorative aspects of a bay can be at odds with a large-scale off-shore wind farm 'industrializing' the area (Devine-Wright \& Howes, 2010) even if renewable energy brings broader environmental benefits. Furthermore, PRSMs influences risk perception, such that people generally have positive meanings of natural landscapes that are also sources of danger, thus reducing likelihood for action in cases where evidence might suggest the contrary (Bonaiuto et al., 2016). Also, PRSMs can influence individuals temporally (Stedman, 2016); meanings can work 'fast' because they are quickly understood and taken up by communities or, conversely, PRSMs can 'slow' down community responses to change because of a desire to hold on to an older meaning (Masterson et al., 2017). In this way, PRSMs and place attachment can be more influential than place attachment alone in explaining community members' perceptions of infrastructure (Brehm et al., 2013; Devine-Wright, 2011; Devine-Wright \& Howes 2010).

Controversies involving residents' perceptions of coastal infrastructure are uniquely influenced by PRSMs and place attachment. For example, Clarke and colleagues (2018) illustrate the role of aesthetics by examining place disruption caused by a sea wall constructed to adapt to flood risk in Clontarf, County Dublin, Ireland. In that case, peoples' PRSMs of a local promenade were largely aesthetic (beautiful environment) and recreational (recreational 
amenity), and so constructing a flood wall was perceived to disrupt their primary attachments to the promenade. In the water-related infrastructure conflicts around dam removals, tangible place meanings (i.e., ecosystem services; Reilly \& Adamowski, 2017) were shown to be at odds between supporters versus those not supporting dam removal, whereas the intangible identity / community meanings did not differ between groups (Reilly et al., 2019). Similarly, in a case of rivershed development along the Niobrara National Scenic River, residents that indicated nature meanings of the river were more likely to mention negative aspects of building development (Davenport \& Anderson, 2005).

Taken together, the perceived impacts of coastal infrastructure projects with widely understood purposes are related to their water-related PRSMs, especially those that are tangible or ecosystem related (Devine-Wright, 2009, Reilly \& Adamowski 2017). Yet, we do not possess the nuanced knowledge of the complex interplay of PRSMs of waterbodies and coastal infrastructure where the function and benefits of it have occurred for many years, and so we turn now to our case of New England's Mount Hope Bay and the Brayton Point Station (BPS) cooling towers that were built along its shores.

\section{Case Background}

Mount Hope Bay’s industrial viewscape (see Figure 1) stands in stark contrast to the littoral backdrop that makes the wider Narragansett Bay estuary a popular destination for leisure seekers (see Figure 2; Dalton et al., 2010). Not only was BPS the most prominent feature of the Mount Hope Bay viewshed, it was also the largest coal-fired power plant in New England (Maloney, 2017). After a fourth generating unit was installed in the 1980s, BPS drew up to a billion gallons of cooling water a day that it was releasing into the bay at higher temperatures. 
Growing evidence showed that the collection and release of water caused serious environmental harm due to entrainment and entrapment of marine life (Gibson, 1994; see also May \& van Rossum, 1995), and by the late 1990s, environmental advocates requested that cooling water intake be regulated pursuant to Section 316(b) of the Clean Water Act (33 U.S.C. $\S 1251$ et seq.). The company, therefore, built two 400 foot closed-cycle cooling towers to recycle BPS's cooling water in order to minimize its impact on the bay. Though the pressure to construct these towers came from some community organizations, the towers were constructed without input or opposition from nearby residents. The towers functioned for six years (2013-2019) and just following the completion of this study, unbeknownst to the participants completing our survey, BPS closed and the towers were demolished in May 2019.

[INSERT FIGURE 1 AND FIGURE 2 HERE]

\section{Current Study}

Through our interdisciplinary collaboration (two environmental psychologists and an environmental political scientist) we identified a unique case to investigate perceptions of coastal infrastructure. Our research examines perceived effects visually obtrusive cooling towers attached to the BPS and expands on recent work that investigates residents' responses to place disruptions beyond renewable energy infrastructures, such as the work by Clarke and colleagues (2018) on the construction of a sea wall. Highly visible infrastructure projects that offer direct, hyperlocal environmental benefits in comparison to renewable energy projects that offer indirect and diffuse future promises of environmental benefits (such as carbon reduction) are critical to examine since they are at once both place disruptive but also place protective. Specifically, we examine how residents' place attachment and their PRSMs inform their perception of the effects of environmentally-protective infrastructure. 
We explore how PRSMs of Mount Hope Bay and of the BPS cooling towers themselves alter their perceptions of impacts of the infrastructure on their coastal community. Given that construction on the towers began nearly a decade prior, the PRSMs offered by respondents in the study represent bay associations that have developed through a meaning-making process between the person and the bay with the towers present. Thus, residents' place attachment and PRSMs, along with the perceived effects of the towers, represents their cognitions after having lived in the area for at least 10 years, just before and during the era with the towers in place.

\section{Methods}

\section{Participants \& Sample}

This survey was approved by an author's institutional ethics review board, and participants provided informed consent. Survey participants were recruited via the drop-off and pick-up survey method (Allred \& Ross-Davis, 2011) between October 2018 and February 2019, before demolition of the towers. The sampling strategy involved randomly selecting 600 of 1800 residences living on one of three streets closest to the shore of Mount Hope Bay. Surveys were hand-delivered to residents at their homes and they were informed that the survey would be collected two days later. For residents not home, surveys were left on the resident's door with a note indicating the pick-up day. Surveys were collected from $N=192$ residents (32\% response rate).

Participants who moved to the area fewer than 10 years ago $(N=24)$ were removed since they did not reside in the area during construction of the towers. The final dataset included 168 participants who were $51 \%$ male and $44 \%$ female and ranged in age from 20 to $94(M=63.30$, $S D=13.46)$. Their political-orientation was generally moderate $(M=3.86, S D=1.42$ on a scale from $1=$ extremely liberal to $7=$ extremely conservative) and they considered themselves 
moderately environmentalist $(M=3.39, S D=1.02$ on a scale from $1=$ not at all to $5=$ very much so). The majority were highly educated (55\% bachelors or graduate degree), were longterm residents $(M=39.40$ years, $S D=19.35)$, and had never worked at BPS $(94 \%)$.

\section{Design \& Measurements}

The survey contained a set of open-ended and closed-ended items. Survey scales utilized in these analyses are a subset from the larger survey about collective action around environmental protection.

\section{PRSMS}

A free association task was utilized to capture, separately, participants' PRSMs of Mount Hope Bay and the BPS cooling towers. They were asked: 'Please list up to five words that come to mind about Mount Hope Bay' and 'Please list up to five words that come to mind about the Brayton Point Cooling Towers' (adapted from Clarke et al., 2018; Devine-Wright \& Howes, 2010). The responses included a wide range of words (e.g., adjectives, verbs, objects), which were coded to describe the content of the PRSMs. Responses were open-coded (Saldaña, 2015) and based on thematic categories and sub-themes that emerged in an iterative coding process (adapted from Clarke et al., 2018). Content analysis was conducted to categorize observable themes, and since many participants did not provide a fourth or fifth response, our analysis focused on the first three responses provided by each participant.

A second researcher coded all responses separately using the predefined thematic categories. For PRSMs of the bay, the researchers initially had 83\% agreement, Cohen's $\boldsymbol{\kappa}=.76$; for PRSMs of the towers the researchers initially had 73\% agreement, Cohen's $\boldsymbol{\kappa}=.66$. Discrepancies were discussed with the addition of a third researcher until consensus was reached.

\section{Place Attachment}


Participants responded to eight statements about their attachment to Mount Hope Bay, such as 'I feel like Mount Hope Bay is part of me' and 'Mount Hope Bay is the best place for what I like to do' (adapted from Clarke et al. 2018). They rated items from 1 (Strongly disagree) to 5 (Strongly agree) and items were averaged to obtain a total score $(M=3.71, S D=0.78, \mathrm{a}=$ 91).

\section{Perceived Effects of the Towers}

Participants responded to ten statements about how positively or negatively the towers impacted different aspects of Mount Hope Bay (adapted from Clarke et al. 2018). Each aspect was rated from 1 (Very negative) to 7 (Very positive). A principal-axis factor analysis was conducted with promax rotation and Kaiser normalization on all ten items. When using the criterion of eigenvalues greater than 1 , two factors accounted for $61.45 \%$ of the total variance. Items loaded onto two main scales: ecological \& health effects of the towers scale containing four items (water quality of the bay, fish \& wildlife, air quality, other human health concerns; from .94 to .79) and aesthetic \& financial effects of the towers scale containing six items (views of the bay, appearance of the power plant, property values, tourism, cultural heritage, recreation; from .84 to .51 ). The items within each scale were averaged to calculate a total score (Ecological and health effects: $M=3.74, S D=1.69, \mathrm{a}=.90$; Aesthetic and financial effects: $M=2.18, S D=$ $1.17, \mathrm{a}=.85$ ). To measure the degree to which residents differentiated the two effects, each resident's aesthetic \& financial effect score was subtracted from the resident's ecological \& health effect score. Higher scores indicated greater perceived differentiation and that ecological $\&$ health effects were rated more positively than aesthetic \& financial effects $(M=1.54, S D=$ $1.50)$.

\section{Results}




\section{Analysis of free association data to identify PRSMs}

Analysis of free association data of PRSMs of the bay revealed that Mount Hope Bay was primarily recognized for its aesthetic, ecological, and recreational meanings (see Table 1). The aesthetic category included visual, ambient (the atmospheric character of place nonspecified) and action-oriented (aesthetic dimension of doing things non-specified) components. The ecological category included references to the ecosystems of the bay and actions, such as fishing, that are focused on ecosystem components. Next, the recreation category included all non-ecological oriented activities, such as boating. The affect category included terms of general positive or negative sentiment. The identity category included reference to place-related differentiation between self and others, while the infrastructure category included references to nearby infrastructure features, and the place category included non-specified place meanings.

Analysis of PRSMs of the towers revealed that by far the most common meanings were aesthetic (see Table 1). These included negative appraisals of the design, their immense size, and their similarity to nuclear towers. Less common, were meanings relating to a perceived uselessness or wastefulness of the towers, and contradictory meanings relating to the towers' function and their usefulness in mitigating negative impacts of the power plant. Other meanings included the affect category including mostly negative emotional reactions, and the negative effects category including meanings related to financial effects such as lower property values, ecological effects such as pollution, and human health effects.

[INSERT TABLE 1 HERE]

\section{Correlation \& Regression Analyses}

We utilized available item analysis procedure for managing missing data for scales (Parent, 2013). Surveys missing responses for more than $25 \%$ of items on a scale used in each 
analysis were removed. Each participant's score for each scale was calculated using data from the remaining answered items. Sample sizes for regressions ranged from $N=127$ to $N=152$, and sensitivity analysis indicates with this smallest sample size and power $=80 \%$, a regression with five predictors would pick up an effect size of $f^{2}=.07$.

First, correlations were run to reveal initial relationships between variables (see Table 2). Place attachment generally had weak negative associations with the perceived effects of the towers and was only significantly correlated with the perceived aesthetic and financial effects of the towers. This indicates that stronger place attachment was particularly related to concerns about how the towers impacted the viewshed, property values, and tourism/recreation, but was less related to perceptions of the ecological \& health impacts of the towers. Interestingly, the perceived ecological and health effects of the towers were strongly positively correlated with the perceived aesthetic and financial effects of the towers. This indicates that residents were generally less likely to differentiate between the effects, and instead perceived the towers as generally negative overall (or less frequently generally positive overall).

[INSERT TABLE 2 HERE]

When examining PRSMs, most were unrelated or negatively correlated with each other. This is unsurprising due to the way they were assessed. Since only three free association responses were coded for each resident, if a resident indicated two PRSMs in one category, then the most they could report is one or zero in another PRSM category. However, PRSMs were often related to perceptions of the towers' effects. Ecological and health effects were more positively perceived by those reporting ecological PRSMs of the bay or functional PRSMs of the towers and were negatively perceived by those reporting affective PRSMs of the towers. Aesthetic and financial effects were more positively perceived by those reporting recreational 
PRSMs of the bay or functional PRSMs of the towers and were negatively perceived by those reporting aesthetic PRSMs of the bay or unnecessary PRSMs of the towers. Importantly, when examining residents' perceived differentiations of the two types of effects, greater differentiation was related to ecological PRSMs of the bay, infrastructural PRSMs of the bay, and function PRSMs of the towers, and less differentiation was related to affective PRSMs of the towers.

To examine relative roles of place attachment and key PRSMs and their potential interactions on perceptions of the towers, three regressions were conducted: one to examine predictors of perceived ecological and health effects, one for perceived aesthetic and financial effects, and one for perceived differentiation of effects. Ecological PRSMs of the bay and Function PRSMs of the tower were included since they each represent the key PRSM of each type that most meaningfully correlated with the perceptions of the towers. Before running each regression, place attachment was centered and ecological PRSMs of the bay and function PSRMs of the towers were dummy coded ( $0=$ No PSRM; $1=$ Yes PRSM).

When examining perceived ecological and health impacts of the towers, the regression was significant $F(5,124)=5.67, p<.001, R^{2}=.19$ (see Table 3). People who reported at least one ecological PRSM about the bay or at least one function PRSM about the towers perceived significantly more positive ecological and health effects. Additionally, those with greater place attachment perceived the towers as having marginally worse ecological and health effects. When examining perceived aesthetic and financial impacts $\left[F(5,146)=5.62, p<.001, R^{2}=.16\right]$, those who reported at least one function PRSM about the towers perceived significantly more positive aesthetic and financial effects. In this case, those with greater place attachment perceived the towers had significantly more negative aesthetic and financial impacts. However, ecological PRSMs about the bay were unrelated. When examining residents' perceived differentiation of 
effects, $\left[F(5,121)=2.65, p=.03, R^{2}=.10\right]$, residents who reported at least one ecological PRSM about the bay or at least one function PRSM about the towers perceived that the ecological \& health effects were greater than aesthetic and financial effects, demonstrating differentiation. However, place attachment did not predict perceived differentiation in effects. [INSERT TABLE 3 HERE]

\section{Discussion}

Residents generally perceived the BPS cooling towers as having overall negative effects on different aspects of the bay and community overall, without differentiating the negative impacts on their views and property values from the positive impacts on the health of the bay and local residents. Residents with stronger place attachment were particularly likely to report more negative aesthetic and financial perceived impacts of the towers, in line with past research finding that coastal infrastructure projects are often perceived more negatively by those with greater place attachment (Clarke et al., 2018).

However, this research also demonstrates that PRSMs are crucial to understanding when residents actually differ in their perceptions of the infrastructure (Devine-Wright, 2011; DevineWright \& Howes, 2010). Aesthetic PRSMs of the bay (reported by $77 \%$ of residents) and of the towers (reported by $93 \%$ of residents) were very widely held. Since such a wide range of residents incorporated these meanings, these meanings were not all that predictive of their perceptions of the towers. The more aesthetic PRSMs of the bay residents reported, the more negatively they perceived the towers' aesthetic and financial impacts, but none of the other perceived effects related to aesthetic PRSMs. Alternately, residents who mentioned ecological PRSMs of the bay or functional PRSMs of the towers were more likely to acknowledge the positive ecological and health effects of the towers, and more likely to differentiate these positive effects while still acknowledging the negative aesthetics and financial impacts of the towers on 
the bay and community. This indicates that those who are more aware of the bay's ecosystems or who are more knowledgeable about the function of the towers better understand towers' purpose, and therefore less likely to make a unilaterally negative assessment of the towers.

Understanding the towers' purpose arises in other PRSMs as well. Those with recreational PRSMs of the bay are more likely to report the towers' positive aesthetic and financial effects, likely driven by perception of the effects on recreation and tourism, but those with unnecessary PRSMs of the towers reported greater negative aesthetic and financial impacts. Additionally, those with affective PRSMs of the towers seemed to have misconceptions of the towers' purpose despite living with them for many years, reporting that the towers led to more negative ecological and health impacts. Past work finds that when an infrastructure is perceived to be aligned with a resident's PRSMs, they are less likely to oppose it (Devine-Wright, 2009). Our research suggests this may be because these residents with ecological, functional, or recreational PRSMs are more able to acknowledge the infrastructure's beneficial effects even if the infrastructure is disruptive in other ways.

Furthermore, PRSMs discern what aspects of the waterbody are important to the individual and shape how the individual perceives related projects (Quinn et al., 2019). In this case PRSMs predict who distinguishes the towers' more positive ecological and health effects from their more negative aesthetic and financial effects, which place attachment alone did not. The different influence of PRSMs in this case connects to the discussion of meanings working fast and slow in shaping subjective perceptions of change and related necessary environmental actions (i.e., Masterson et al., 2017; Stedman, 2016). In this case, the ecological PRSMs of the bay and the functional PRSMs of the towers appear to support individuals to be 'faster' in perceiving change and the necessity of environmental actions, evidenced by their positive 
perceptions of the towers' effects. Conversely, those holding aesthetic PRSMs of the bay and towers emphasized the viewshed that unlike the ecological emphasis, was only adversely affected by the construction of the towers. Thus, the focus on the viewshed meant that they were 'slow' to accept the towers, perhaps because they were more focused on the aesthetics of the bay and so were slow to perceive the environmental issues in the bay.

These findings have applications that may support conflict-resolution in infrastructure projects. Specifically, attending to tangible place meanings such as those relating to ecosystems and aesthetics, may help to clarify aspects of disagreement (Reilly \& Adamowski, 2017). While our results show that residents tended to simplify their perceptions of the towers' effects as wholly good or wholly bad, PRSMs related to the ecology of the bay or the function of the towers led to more diversified perceptions. For future water-protective infrastructure projects, this suggests a need for developers to consider the co-construction of place meanings in their outreach efforts (Quinn et al., 2019). It also reveals a key role for interventions intended to boost ecological place meanings (i.e., Russ et al., 2015), such as environmental education and other outreach that supports collective learning about water bodies and water-related infrastructure. This may help to shift residents' emphasis from primarily aesthetic place meanings to more complex interpretations that include ecological benefits.

While our study identifies key insights about residents' perceptions of the effects of large-scale infrastructure, we remain cautious about overstating our conclusions. The towers were constructed on a pre-existing industrial coastline, so our findings may not be generalizable to less-developed coastal places. Residents living close to the bay's shoreline may also differ in comparison to non-resident users of the bay. Future research exploring similar coastal infrastructure projects should consider non-resident users as well as user groups for whom place 
attachment and PRSMs have very specific and significant connotations, such as commercial fishermen, communities forced to bear a greater burden of environmental pollutants, and indigenous communities with ancestral relationships to those places.

Taken together, this study offers evidence for the important role of PRSMs in shaping perceptions of coastal infrastructure. It demonstrates that while many residents focus largely on aesthetic meanings of the waterbody and infrastructure, those that also include ecological meanings of the waterbody or functional meanings of the infrastructure have more nuanced perceptions of the positive and negative effects of such projects on the waterbody and local community. 


\section{References}

Adger, W. N., Dessai, S., Goulden, M., Hulme, M., Lorenzoni, I., Nelson, D. R., Naess, L.O., Wolf, J., \& Wreford, A. (2009). Are there social limits to adaptation to climate change? Climatic Change, 93(3), 335-354. https://doi.org/10.1007/s10584-008-9520-z

Allred, S. B., \& Ross-Davis, A. (2011). The drop-off and pick-up method: An approach to reduce nonresponse bias in natural resource surveys. Small-Scale Forestry, 10, 305-318. https://doi.org/10.1007/s11842-010-9150-y

Bonaiuto, M., Alves, S., De Dominicis, S., \& Petruccelli, I. (2016) Place attachment and natural hazard risk: Research review and agenda. Journal of Environmental Psychology, 48, 3353. https://doi.org/10.1016/j.jenvp.2016.07.007

Brehm, J. M., Eisenhauer, B. W., \& Stedman, R. C. (2013). Environmental concern: Examining the role of place meaning and place attachment. Society \& Natural Resources, 26, $522-$ 538. https://doi.org/10.1080/08941920.2012.715726

Clarke, D., Murphy, C., \& Lorenzoni, I. (2018). Place attachment, disruption and transformative adaptation. Journal of Environmental Psychology, 55, 81-89. https://doi.org/10.1016/j.jenvp.2017.12.006

Dalton, T., Thompson, R., \& Jin, D. (2010). Mapping human dimensions in marine spatial planning and management: An example from Narragansett Bay, Rhode Island. Marine Policy, 34, 309-319. https://doi.org/10.1016/j.marpol.2009.08.001

Davenport, M. A., \& Anderson, D. H. (2005). Getting from sense of place to place-based management: An interpretive investigation of place meanings and perceptions of landscape change. Society \& Natural Resources, 18(7), 625-641. https://doi.org/10.1080/08941920590959613 
Devine-Wright, P. (2009). Rethinking NIMBYism: The role of place attachment and place identity in explaining place-protective action. Journal of Community \& Applied Social Psychology, 19(6), 426-441. https://doi.org/10.1002/casp.1004

Devine-Wright, P. (2011). Place attachment and public acceptance of renewable energy: A tidal energy case study. Journal of Environmental Psychology, 31, 336-343. https://doi.org/10.1016/j.jenvp.2011.07.001

Devine-Wright, P., \& Howes, Y. (2010). Disruption to place attachment and the protection of restorative environments: A wind energy case study. Journal of Environmental Psychology, 30, 271-280. https://doi.org/10.1016/j.jenvp.2010.01.008

Devine-Wright, P., \& Wiersma, B. (2019). Understanding community acceptance of a potential offshore wind energy project in different locations: An island-based analysis of 'placetechnology fit'. Energy Policy, 137, https://doi.org/10.1016/j.enpol.2019.111086

Enqvist, J. P., Campbell, L. K., Stedman, R. C., \& Svendsen, E. S. (2019). Place meanings on the urban waterfront: a typology of stewardships. Sustainability Science, 14(3), 589-605. https://doi.org/10.1007/s11625-019-00660-5

Firestone, J., Bates, A., \& Knapp, L. A. (2015). See me, feel me, touch me, heal me: Wind turbines, culture, landscapes, and sound impressions. Land Use Policy, 46, 241-249. https://doi.org/10.1016/j.landusepol.2015.02.015

Freudenburg, W. R., \& Pastor, S. K. (1992). NIMBYs and LULUs: Stalking the syndromes. Journal of Social Issues, 48, 39-61. https://doi.org/10.1111/j.1540-4560.1992.tb01944.x Gibson, M. R. (1994). Population dynamics of winter flounder in Mt. Hope Bay in relations to 
operations at the Brayton Point Electric Plant. Report to the Brayton Point Technical Advisory Committee, May 1992. Revised December 1993. Rhode Island Division Fish and Wildlife.

Low, S. M., \& Altman, I. (1992). Place attachment. In I. Altman \& S. M. Low (Eds.), Place attachment (pp. 279-304). Boston, MA: Springer.

Maloney, P. (2017, November 22). Dynegy strikes deal to sell Brayton Point, once New England's largest coal plant. Utility Dive. Retrieved from: https://www.utilitydive.com/news/dynegy-strikes-deal-to-sell-brayton-point-once-newenglands-largest-coal/511558/

Manzo, L. C., \& Perkins, D. D. (2006). Finding common ground: The importance of place attachment to community participation and planning. Journal of Planning Literature, 20, 335-350. https://doi.org/10.1177/0885412205286160

Masterson, V. A., Stedman, R. C., Enqvist, J., Tengö, M., Giusti, M., Wahl, D., \& Svedin, U. (2017). The contribution of sense of place to social-ecological systems research: A review and research agenda. Ecology and Society, 22(1). https://doi.org/10.5751/ES$\underline{08872-220149}$

May, J. R., \& van Rossum, M. K. (1995). The quick and the dead: Fish entrainment, entrapment, and the implementation and application of Section 316(b) of the Clean Water Act. Vermont Law Review. 20, 373-493.

McLachlan, C. (2009). 'You don't do a chemistry experiment in your best china': Symbolic interpretations of place and technology in a wave energy case. Energy Policy, 37(12), 5342-5350. https://doi.org/10.1016/j.enpol.2009.07.057

Parent, M. C. (2013). Handling item-level missing data: Simpler is just as good. The Counseling 
Psychologist, 41, 568-600. https://doi.org/10.1177/0011000012445176

Proshansky, H. M., Fabian, A. K., \& Kaminoff, R. (1983). Place-identity: Physical world socialization of the self. Journal of Environmental Psychology, 3, 57-83. https://doi.org/10.1016/S0272-4944(83)80021-8

Quinn, T., Bousquet, F., Guerbois, C., Heider, L., \& Brown, K. (2019). How local water and waterbody meanings shape flood risk perception and risk management preferences. Sustainability Science, 14(3), 565-578. https://doi.org/10.1007/s11625-019-00665-0

Rand, J., \& Hoen, B. (2017). Thirty years of North American wind energy acceptance research: What have we learned? Energy Research \& Social Science, 29, 135-148. https://doi.org/10.1016/j.erss.2017.05.019

Reilly, K. H., \& Adamowski, J. F. (2017). Stakeholders' frames and ecosystem service use in the context of a debate over rebuilding or removing a dam in New Brunswick, Canada. Ecology and Society, 22(1), 17. https://doi.org/10.5751/ES-09045-220117

Reilly, K., Adamowski, J., \& John, K. (2019). The role of place meanings in opposition to water related infrastructure projects: the case of the Mactaquac Dam, New Brunswick, Canada. Ecology and Society, 24(4), 34. https://doi.org/10.5751/ES-10811-240429

Russ, A., Peters, S. J., E. Krasny, M., \& Stedman, R. C. (2015). Development of ecological place meaning in New York City. The Journal of Environmental Education, 46(2), 73-93. https://doi.org/10.1080/00958964.2014.999743

Saito, Y. (2004). Machines in the ocean: The aesthetics of wind farms. Contemporary Aesthetics, 2. Retrieved from: https://digitalcommons.risd.edu/liberalarts_contempaesthetics/vol2/iss1/6/ Saldaña, J. (2015). The coding manual for qualitative researchers. London: Sage. 
Stedman, R. (2002). Toward a social psychology of place: Predicting behaviour from place-based cognitions, attitude, and identity. Environment and Behavior, 34, 561-581. https://doi.org/10.1177/0013916502034005001

Stedman, R. C. (2016). Subjectivity and social-ecological systems: a rigidity trap (and sense of place as a way out). Sustainability Science, 11(6), 891-901. https://doi.org/10.1007/s11625-016-0388-y

Tonge, J., Moore, S. A., Ryan, M. M., \& Beckley, L. E. (2013) A photo-elicitation approach to exploring the place meanings ascribed by campers to the Ningaloo coastline, northwestern Australia. Australian Geographer, 44(2), 143-160. https://doi.org/10.1080/00049182.2013.789591

Wynveen, C. J., Kyle, G. T., \& Sutton, S. G. (2012). Natural area visitors' place meaning and place attachment ascribed to a marine setting. Journal of Environmental Psychology, 32(4), 287-296. https://doi.org/10.1016/j.jenvp.2012.05.001 
Table 1: Residents' PRSMs for Mount Hope Bay and of the Brayton Point Cooling Towers as identified from free association responses

\begin{tabular}{|c|c|c|c|c|c|}
\hline $\begin{array}{l}\text { Thematic } \\
\text { categories }\end{array}$ & Common responses (number of responses) & $\begin{array}{l}\text { Residents } \\
\text { reporting } \\
\text { PRSM at } \\
\text { least once }\end{array}$ & $\begin{array}{l}\text { First } \\
\text { response } \\
(n=160)\end{array}$ & $\begin{array}{l}\text { Second } \\
\text { response } \\
(n=148)\end{array}$ & $\begin{array}{l}\text { Third } \\
\text { response } \\
(n=124)\end{array}$ \\
\hline \multicolumn{6}{|c|}{ Residents' PRSMs of the Bay } \\
\hline Aesthetic & $\begin{array}{l}\text { Beautiful (70), Scenic (19), Peaceful (16), Fun (12), Clean } \\
\text { (10), Relaxing (10) }\end{array}$ & $77 \%$ & $62 \%$ & $52 \%$ & $44 \%$ \\
\hline Ecological & $\begin{array}{l}\text { Fish/fishing (24), Shellfish/quahogs (10), Natural (7), } \\
\text { Water (4), Seafood (4) }\end{array}$ & $38 \%$ & $12 \%$ & $20 \%$ & $25 \%$ \\
\hline Recreation & Boating (17), Recreation (15), Swimming (9), Sailing (5) & $29 \%$ & $10 \%$ & $18 \%$ & $14 \%$ \\
\hline Affect & Positive (17), Calm (3) & $14 \%$ & $8 \%$ & $5 \%$ & $2 \%$ \\
\hline Identity & Home (8) & $8 \%$ & $5 \%$ & $3 \%$ & $2 \%$ \\
\hline Place & N/A & $7 \%$ & $1 \%$ & $1 \%$ & $7 \%$ \\
\hline Infrastructure & Bridge (4) & $5 \%$ & $2 \%$ & $1 \%$ & $5 \%$ \\
\hline Other & N/A & $2 \%$ & $1 \%$ & $1 \%$ & $2 \%$ \\
\hline \multicolumn{6}{|c|}{ Resident's PRSMs of the Towers } \\
\hline Aesthetic & Ugly (76), Eyesore (51), Nuclear (21), Huge (12), Big (9) & $93 \%$ & $84 \%$ & $63 \%$ & $53 \%$ \\
\hline Unnecessary & $\begin{array}{l}\text { Unnecessary/useless (9), Waste of money (9), } \\
\text { Demolish/Take down (8), Wasteful (6), Unclear purpose } \\
\text { (4) }\end{array}$ & $21 \%$ & $4 \%$ & $13 \%$ & $12 \%$ \\
\hline Function & Necessary/Needed (10), Cools water in bay (7) & $17 \%$ & $5 \%$ & $7 \%$ & $14 \%$ \\
\hline Affect & $\begin{array}{l}\text { Three Mile Island (4), Disturbing (3), Frightening/Scary } \\
\text { (3) }\end{array}$ & $15 \%$ & $5 \%$ & $5 \%$ & $7 \%$ \\
\hline $\begin{array}{l}\text { Negative } \\
\text { Impacts }\end{array}$ & $\begin{array}{l}\text { Lower property values (9), Pollution (6), Heats water (5), } \\
\text { Harms bay/animals (4), Health (3) }\end{array}$ & $13 \%$ & $3 \%$ & $9 \%$ & $12 \%$ \\
\hline Other & N/A & $3 \%$ & $0 \%$ & $3 \%$ & $2 \%$ \\
\hline
\end{tabular}

Note: Common responses include the five most commonly provided responses within a thematic category that were stated by at least three different participants. More than five responses are listed in a category if several responses had the same lowest frequency. 
Table 2: Pearson Correlations between Study Variables

Variable

$1 \quad 2 \quad 3$

4

5

6

1. Place Attachment

2. Perceived Ecological \& Health Effects -.16* --

3. Perceived Aesthetic \& Financial Effects $\quad-.25^{*} \quad .50^{* *} \quad--$

4. Perceived Differentiation of Effects $\quad .02 \quad .73 * * \quad-.23 * \quad--$

5. Aesthetic PRSM Bay

6. Ecological PRSM Bay

$\begin{array}{lllll}.11 & -.15 & -.18^{*} & -.05 & -.\end{array}$

7. Recreation PRSM Bay

8. Affect PRSM Bay

9. Identity PSRM Bay

10. Infrastructure PRSM Bay

11. Place PSRM Bay

12. Aesthetic PRSM Towers

13. Function PRSM Towers

14. Affect PRSM Towers

15. Unnecessary PRSM Towers

$\begin{array}{llllll}.10 & .19 * & .00 & .23 * & -.43 * * & -\end{array}$

$\begin{array}{llllll}-.05 & .05 & .19 * & -.02 & -.48 * * & .12\end{array}$

$\begin{array}{llllllll}.05 & -.13 & -.06 & -.05 & -.06 & -.13 & -.09 & --\end{array}$

$\begin{array}{lllllllll}.25 * & -.06 & -.06 & -.01 & -.09 & -.03 & -.05 & -.06 & --\end{array}$

$\begin{array}{lllllllllll}-.16 * & .10 & -.07 & .16 * & -.19 * & -.06 & .13 & -.03 & -.06 & --\end{array}$

$\begin{array}{llllllllllllll}-.13 \dagger & .11 & .03 & .11 & -.03 & -.08 & -.08 & -.04 & -.08 & -.06 & --\end{array}$

$\begin{array}{llllllllllllll}-.06 & .01 & -.12 & .11 & .16^{*} & -.08 & -.05 & .06 & -.01 & .04 & .001 & --\end{array}$

$\begin{array}{llllllllllllll}.06 & .31 * * & .28 * * & .16 * & -.09 & .10 & .10 & .002 & -.01 & .03 & .03 & -.34 * * & --\end{array}$

$\begin{array}{lllllllllllllllllll}.14 & -.20 * & .01 & -.20 * & .03 & .03 & .06 & -.02 & -.07 & -.09 & -.04 & -.25 * * & -.08 & --\end{array}$

$\begin{array}{lllllllllllllllllll}-.07 & -.15 & -.20 * & -.01 & -.03 & -.02 & -.02 & -.02 & .10 & .07 & .07 & -.33 * * & -.08 & -.14 & --\end{array}$

16. Negative Impacts PRSM Towers

$\begin{array}{lllllllllllllll}-.10 & .01 & -.11 & .06 & -.09 & .19 * & .14 * & -.08 & .05 & .004 & -.01 & -.34 * * & -.09 & \end{array}$

Note: ${ }^{*} p<.05, * * p<.001$. PRSM scores range from $0-3$, indicating the number of times a particular PRSM is listed as a freeassociation response for each resident 
Table 3. Regression of Place Attachment, Ecological PRSM of Bay, Function PRSM of Towers, and their interactions on Resident's Perceived Effects of the Towers

\begin{tabular}{|c|c|c|c|c|c|c|c|c|c|c|c|c|}
\hline \multirow[b]{2}{*}{ Variable } & \multicolumn{4}{|c|}{$\begin{array}{l}\text { Perceived Ecological \& Health } \\
\text { Effects of the Towers }(N=130)\end{array}$} & \multicolumn{4}{|c|}{$\begin{array}{l}\text { Perceived Aesthetic \& Financial } \\
\text { Effects of the Towers }(N=152)\end{array}$} & \multicolumn{4}{|c|}{$\begin{array}{l}\text { Perceived Differentiation in } \\
\text { Effects of the Towers }(N=127)\end{array}$} \\
\hline & $B$ & $S E(B)$ & $\beta$ & $\begin{array}{c}95 \% \mathrm{CI} \\
\text { for } B\end{array}$ & $B$ & $\begin{array}{l}S E \\
(B)\end{array}$ & $\beta$ & $\begin{array}{c}95 \% \text { CI for } \\
B\end{array}$ & $B$ & $\begin{array}{l}S E \\
(B)\end{array}$ & $\beta$ & $\begin{array}{c}95 \% \mathrm{CI} \\
\text { for } B\end{array}$ \\
\hline Place Attachment & -0.35 & 0.20 & -.16 & $-0.75,0.05$ & -0.45 & 0.13 & $-0.31 *$ & $-.071,-0.19$ & 0.11 & 0.19 & .06 & $-0.26,0.48$ \\
\hline $\begin{array}{l}\text { Ecological PRSM } \\
\text { Bay }\end{array}$ & 0.72 & 0.30 & $.20 *$ & $0.13,1.31$ & -0.03 & 0.19 & -0.01 & $-0.40,0.34$ & 0.70 & 0.28 & $.22 *$ & $0.14,1.24$ \\
\hline $\begin{array}{l}\text { Function PRSM } \\
\text { Towers }\end{array}$ & 1.75 & 0.40 & $.38 * *$ & $0.96,2.54$ & 0.86 & 0.24 & $0.28 *$ & $0.38,1.34$ & 1.03 & 0.38 & $.25^{*}$ & $0.28,1.79$ \\
\hline $\begin{array}{l}\text { Place Attachment } \\
\text { x Ecological } \\
\text { PRSM }\end{array}$ & -0.21 & 0.43 & -.05 & $-1.07,0.64$ & 0.04 & 0.27 & 0.01 & $-0.50,0.58$ & -0.38 & 0.40 & -.09 & $-1.11,0.47$ \\
\hline $\begin{array}{l}\text { Place Attachment } \\
\text { x Function PRSM }\end{array}$ & -0.54 & 0.64 & -.08 & $-1.80,0.72$ & 0.53 & 0.37 & 0.13 & $-0.21,1.27$ & -0.79 & 0.60 & -.14 & -1.980 .39 \\
\hline
\end{tabular}




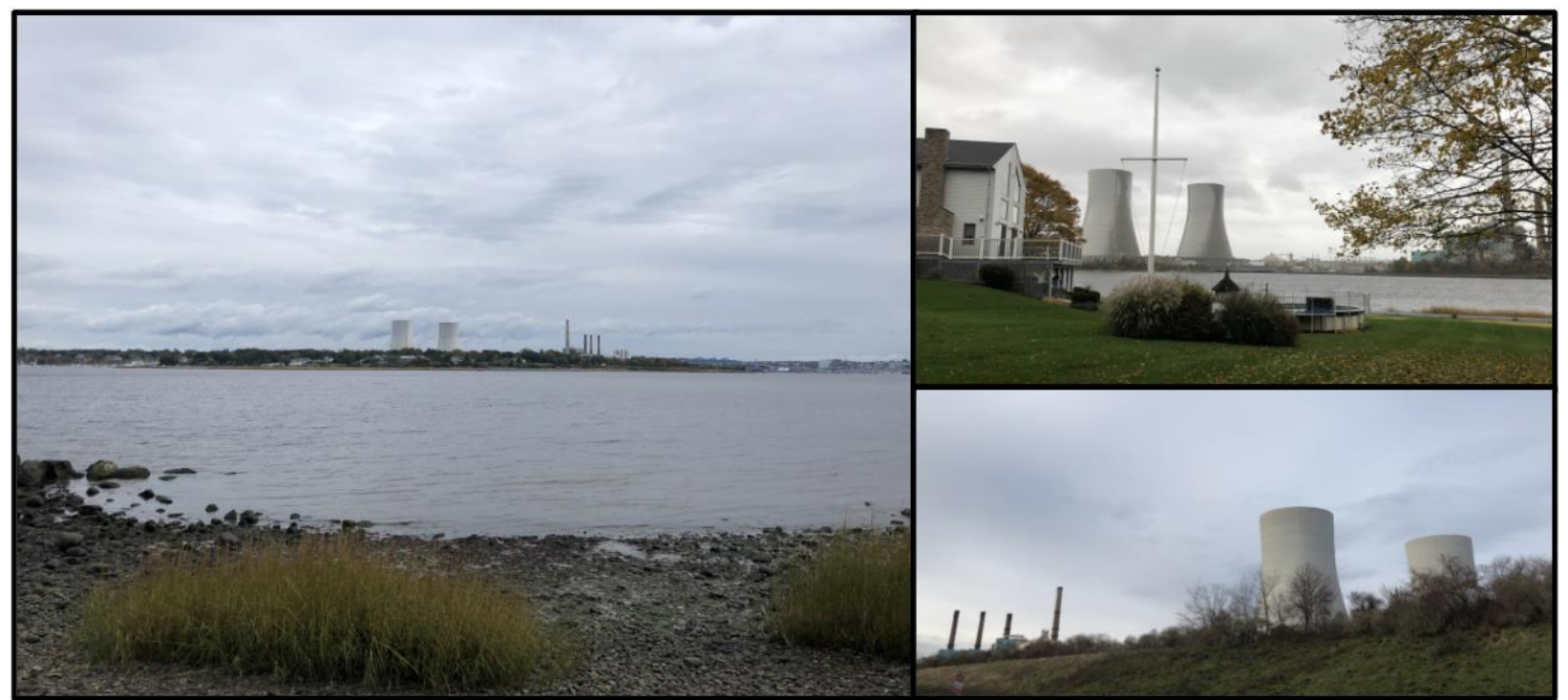

Figure 1: View of the Brayton Point Power Plant L to R: looking east from Bristol, RI, looking east from Touisset Point, RI; and looking west from Somerset, MA. 


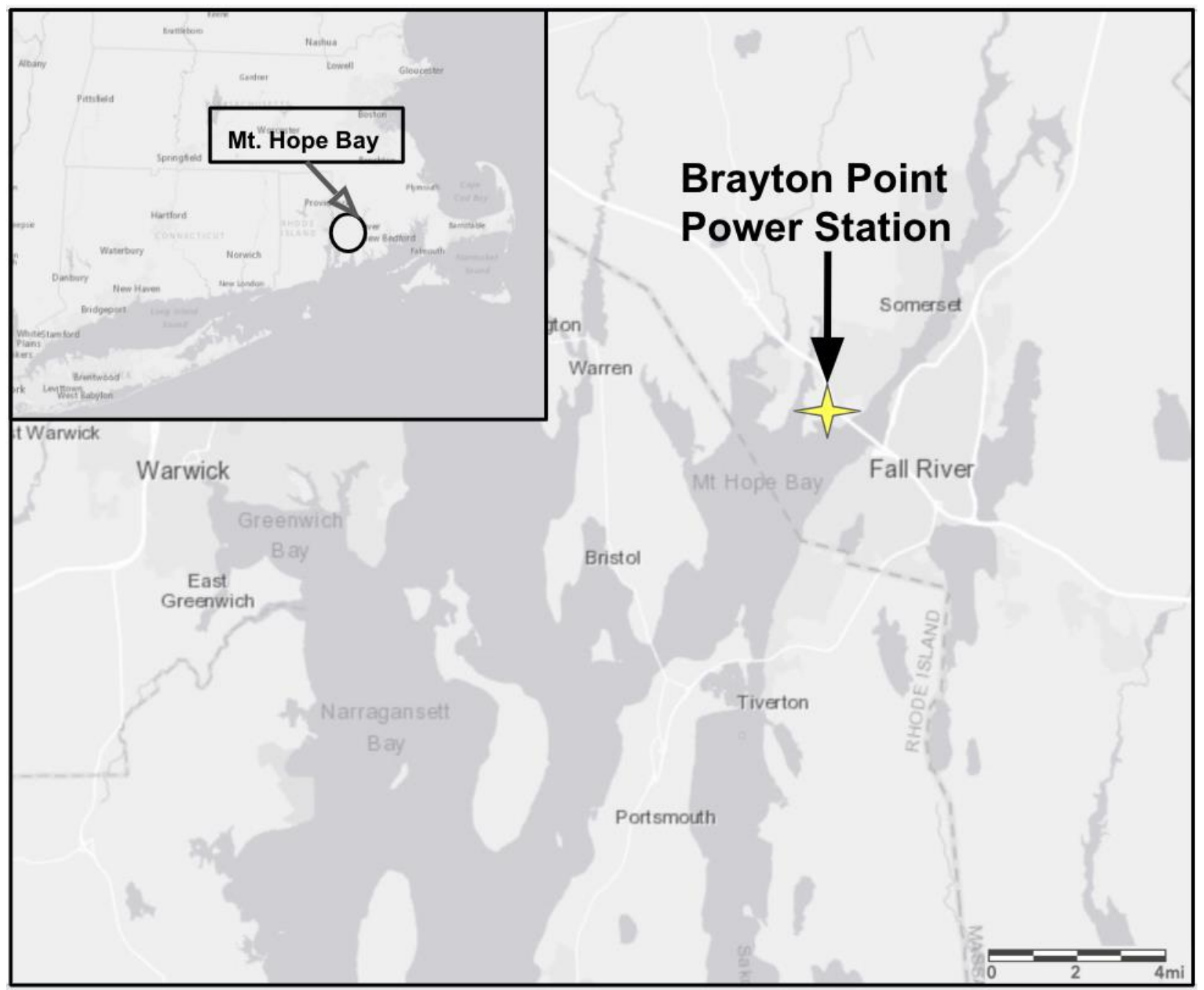

Figure 2: Map of Brayton Point Power Station and Mount Hop 